\title{
Adsorption Equilibrium, Kinetics, Thermodynamics and Dynamic Separation of Magnesium and Calcium Ions from Industrial Wastewater by New Strong Acid Cation Resin of SPVC
}

\author{
Dilfuza Nuriddinova ${ }^{1}$, Farkhod Yusupov $^{2}$, Elyor Berdimurodov ${ }^{1}$, \\ Normahmat Yodgorov $^{2}$ and Murod Mamanazarov ${ }^{2}$ \\ ${ }^{1}$ Department of Natural Sciences, Karshi State University, Kuchabog 17, Karshi, 180100, Uzbekistan. \\ ${ }^{2}$ Institute of General and Nonorganic Chemistry, Academy of the science of the Republic of Uzbekistan, Feruza 39, \\ Mirzo Ulugbek, Tashkent, 100180, Uzbekistan. \\ *Corresponding Author Email: elyor170690@gmail.com \\ Received 05 October 2020, Revised 04 June 2021, Accepted 06 June 2021
}

\begin{abstract}
In the research work, the adsorption equilibrium, kinetics, thermodynamics and dynamic separation of magnesium and calcium ions from industrial wastewater by new strong acid cation resin of SPVC (sulphonated polyvinylchloride) were investigated. The sorption capacity of the studied resin was $3.78 \mathrm{mmol} / \mathrm{g}$ and $3.74 \mathrm{mmol} / \mathrm{g}$ for magnesium and calcium ions, respectively, according to Langmuir isotherm. It was found that the pseudo-first-order model was better fitted for the adsorption kinetics of magnesium and calcium ions on the resin. The dynamic separation results confirmed that the selected resin effectively separated magnesium and calcium ions from industrial wastewater in the dynamic condition. The change of the standard Gibbs free energy $\left(\Delta \mathrm{G}^{\circ}\right)$ and enthalpy $\left(\Delta \mathrm{H}^{\circ}\right)$, and entropy $\left(\Delta \mathrm{S}^{\circ}\right)$ were calculated. The obtained results confirmed that the adsorption of magnesium and calcium ions on the selected resin is endothermic.
\end{abstract}

Keywords: Magnesium and calcium ions, Dynamic separation, Kinetics, Adsorption equilibrium, Strong acid cation resin.

\section{Introduction}

The separation of $\mathrm{Mg}^{2+}$ and $\mathrm{Ca}^{2+}$ ions from industrial wastewater is an important task in the chemical industry [1]. The $\mathrm{Mg}^{2+}$ and $\mathrm{Ca}^{2+}$ ions in the wastewater cause many problems, for instance, the operation and cost problems [2]. The industrial wastewater solution with more $\mathrm{Mg}^{2+}$ and $\mathrm{Ca}^{2+}$ ions is difficult for water-recycling processes [3]. As a result, the separation of $\mathrm{Mg}^{2+}$ and $\mathrm{Ca}^{2+}$ ions from wastewater has an important role in water recycling operation [4]. Modern separation methods are expensive and not environmental friendly. In addition to this, the modern methods are not high ionic capacity compounds. The capacity volume is an important task in separation science. Therefore, creating more effective and green water recycling technology is an important task in the chemical industry.

In the water recycling technology, the strong acid cation resin was used to remove $\mathrm{Mg}^{2+}$ and $\mathrm{Ca}^{2+}$ ions from the wastewater solution [5]. This method is cost-effective and more efficient [6]. Some scientific groups investigated and created a new type of strong 
acid cation resin for the separation of metal ions from wastewater solutions [7]. For example, Lü et al., investigated the resin $001 \times 7$ sorption characteristics for $\mathrm{Mg}^{2+}$ and $\mathrm{Ca}^{2+}$ ions; it was found that its maximal sorption capacity for $\mathrm{Mg}^{2+}$ and $\mathrm{Ca}^{2+}$ ions were 1.83 and $1.86 \mathrm{mmol} / \mathrm{g}$, respectively [1]. Yu et al., researched the Amberlite IRC 748 synthetic resin for separation for $\mathrm{Mg}^{2+}$ and $\mathrm{Ca}^{2+}$ ions from wastewater solution, and the obtained result indicated that the maximum ion exchange capacity of this resin for $\mathrm{Mg}^{2+}$ and $\mathrm{Ca}^{2+}$ ions were 27.70 and $47.21 \mathrm{mg} / \mathrm{g}$, respectively [2]. Some researcher groups used the sulfonated cation-exchange resins for the separation of organic acids from industrial wastewater. For example, P. N. Nesterenko et $a l$. investigated that the sorption nature of sulfonated cation-exchange resins based on the highly cross-linked polystyrenedivinylbenzene ( $80 \%$ divinylbenzene) and hypercrosslinked polystyrene (HCPS) for organic acid. The results demonstrated that these cation resins were effective sorbents for aliphatic carboxylic acids. Because these cation resins have large active surface areas, which support the high mass exchange and good sorption behavior [8]. Leng et al., studied the sorption mechanism and kinetics of Sinco-430 cation exchange resin for iron in the phosphoric acid solution. The obtained results confirmed that the $-\mathrm{SO}_{3} \mathrm{H}$ functional groups in this cation resin is responsible for iron sorption because these functional groups strongly linked with iron ions to form chemical bonds; the sorption nature of this resin was stable around $50{ }^{\circ} \mathrm{C}$ [9]. Elgoud et $a l$., studied that the sorption thermodynamics of Lewatit CNP80 cation resin for Pb (II) ions in the battery industry wastewater [10]. This resin was synthesized based on the acrylic polymers, which contained the functionalized carboxylic $(-\mathrm{COOH})$ groups and cross-linked divinylbenzene. The active $-\mathrm{COOH}$ groups contributes to effectively remove $\mathrm{Pb}$ (II) ions from the battery industry wastewater [11]. The straight-chain alkenes $(\mathrm{C} 9, \mathrm{C} 16)$ were utilized to synthesize the new type of sulfonated cation resins with the help of Lewatit K2640, Lewatit K2431 [12], Tulsion 66 MP, and Amberlyst 15 catalysts, indicating that the hydroxyl functional groups in these resins support to be excellent the sorption capacity nature [12]. This is because these functional groups are more acidic. They are directly linked with aromatic rings and this indicates support to be more acid [12].

The novelty of this work is that the adsorption equilibrium, kinetics, thermodynamics and dynamic separation of $\mathrm{Mg}^{2+}$ and $\mathrm{Ca}^{2+}$ ions from industrial wastewater by new strong acid cation resin were introduced and investigated. The SPVC strong acid cation resin was selected for separation for $\mathrm{Mg}^{2+}$ and $\mathrm{Ca}^{2+}$ ions from industrial wastewater. Because this resin is easily synthesized based on local products, and excellent sorption capacity for $\mathrm{Mg}^{2+}$ and $\mathrm{Ca}^{2+}$ ions and easily regenerated. The selected resin is economical more efficient because it is easily synthesized based on local products. It can support to become cost-effective.

\section{Materials and Methods Materials and Chemicals}

In this research article, the sulphonated polyvinylchloride (SPVC) strong acid cation resin was used, which was synthesized and characterized related to a previously reported synthetic methodology [4], and its characteristics were indicated in Table 1. Before using the SPVC, it was initially submerged in the deionized water for $48 \mathrm{~h}$, next in $4 \mathrm{wt} \% \mathrm{NaOH}$ solution for $10 \mathrm{~h}$, and then $4 \mathrm{wt} \% \mathrm{H}_{2} \mathrm{SO}_{4}$ solutions for $4 \mathrm{~h}$. After each dip, SPVC was washed with deionized water until the resulting water became neutral, and in the last step [13], it was dried at $70^{\circ} \mathrm{C}$. 
Table 1. Specifications of SPVC strong acid cation resin.

\begin{tabular}{lc}
\hline \multicolumn{1}{c}{ Specifications } & Values \\
\hline $\mathrm{pH}$ range & $1 \sim 14$ \\
Maximum operating & $150{ }^{\circ} \mathrm{C}$ \\
temperature & $\geq 96 \%$ \\
Particle size $(0.3 \sim 1.2 \mathrm{~mm})$ & $44-57 \%$ \\
Moisture holding capacity & $1.24-1.29$ \\
Specific gravity & $\geq 3.78$ Equiv./L \\
Total exchange capacity & $\mathrm{Na}^{+}$ \\
Ionic form & Sulphonates \\
Functional groups & Plastic polyvinyl chloride polymer \\
Matrix
\end{tabular}

\section{Industrial wastewater}

In the research work, the industrial wastewater was used as a working solution, which was obtained from Mubarak oil and gas LTD Company in Uzbekistan. The composition of the wastewater be presented: $\mathrm{Mg}^{2+}$ was $88 \mathrm{mg} / \mathrm{L} ; \mathrm{Ca}^{2+}$ was $34 \mathrm{mg} / \mathrm{L} ; \mathrm{Cl}^{-}$ was $78 \mathrm{mg} / \mathrm{L}, \mathrm{Ca}_{4}{ }^{-2}$ was $24 \mathrm{mg} / \mathrm{L}$; there is a very low concentration (under $0.5 \mathrm{mg} / \mathrm{L}$ of other cations, which not influence the experiments).

\section{Adsorption Isotherms}

To identify the adsorption isotherms, the following acts were conducted. In batch observations, a various $50 \sim 300 \mathrm{mmol} / \mathrm{L}$

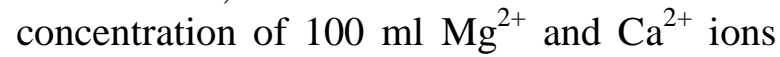
solutions with distilled water were prepared from $\mathrm{CaCl}_{2}$ or $\mathrm{MgCl}_{2}$ and subsequently agitated with the SPVC strong acid cation resin at $293 \mathrm{~K}$ [14]. The mass of resin added was $1 \mathrm{~g}$, and the equilibration time is $10 \mathrm{~min}$. The adsorption values of $\mathrm{Mg}^{2+}$ and $\mathrm{Ca}^{2+}$ ions on the resin phase at equilibrium $\left(\mathrm{q}_{\mathrm{e}}\right.$, $\mathrm{mmol} / \mathrm{g}$ ) were calculated using the following eq. (1) [15].

$$
\mathrm{q}_{\mathrm{e}}=\frac{\left(\mathrm{C}_{\mathrm{o}}-\mathrm{C}_{\mathrm{e}}\right) \mathrm{V}}{\mathrm{m}}
$$

where $m$ is the weight of dry sorbent at $\mathrm{g}$, $V$ is the solution volume at $\mathrm{L}, \mathrm{C}_{\mathrm{o}}$ is the first and $C_{\mathrm{e}}$ is the equilibrium concentration at $\mathrm{mmol} / \mathrm{L}$ in the aqueous phase, respectively [16].

It was found that an exceptional exchange capacity of SPVC strong acid cation resin was higher than in divinylbenzene - styrene-based resins. This is due to the SPVC is an excellent sorbent for selected ions. The more sulfonated functional groups in the SPVC support to be an excellent cation exchanger. The Freundlich and Langmuir isotherms were described according to eq. (2) and eq. (3) [17], and utilized for testing the observed results.

$$
\begin{aligned}
& \lg \mathrm{q}_{\mathrm{e}}=\lg \mathrm{k}_{\mathrm{f}}+\left(\frac{1}{\mathrm{n}}\right) \lg \mathrm{C}_{\mathrm{e}} \\
& \frac{\mathrm{C}_{\mathrm{e}}}{\mathrm{q}_{\mathrm{e}}}=\frac{\mathrm{C}_{\mathrm{e}}}{\mathrm{q}_{\mathrm{m}}}+\frac{1}{\mathrm{q}_{\mathrm{m}} \mathrm{b}}
\end{aligned}
$$

Where $b$ is exponentially equal to the adsorption heat and, and undergoes the Langmuir constant at $\mathrm{g} / \mathrm{mmol}, q_{m}$ indicates the maximum adsorption capacity at $\mathrm{mmol} / \mathrm{g}, k_{f}$ shows the Freundlich constant at $\mathrm{mmol} / \mathrm{L}$ and $n$ reveals the adsorption strength [18].

\section{Adsorption Kinetics}

The batch adsorption kinetics observations were performed in $100 \mathrm{~mL}$ pure water and industrial wastewater solutions at various period $(0 \sim 120 \mathrm{~min})$ with the resin. The amounts of $\mathrm{Mg}^{2+}$ and $\mathrm{Ca}^{2+}$ ions in the solutions before and after adsorption were calculated by the titrimetric analysis [19]. The $\mathrm{CaCl}_{2}$ and $\mathrm{MgCl}_{2}$ salts were used to prepare the synthetic solutions. The industrial wastewater was obtained from Mubarak oil and gas LTD Company in Uzbekistan.

The observed data of adsorption kinetics were measured through the pseudo-first-order and the pseudo-second-order models, which can be 
described according to eq. (4) and eq. (5) [20], respectively:

$$
\begin{aligned}
& \mathrm{q}_{\mathrm{t}}=\mathrm{q}_{\mathrm{e}}\left(1-\mathrm{e}^{\mathrm{k}_{1} \mathrm{t}}\right) \\
& \mathrm{q}_{\mathrm{t}}=\frac{\mathrm{k}_{2} \mathrm{q}_{\mathrm{e}}^{2} \mathrm{t}}{1+\mathrm{k}_{2} \mathrm{q}_{\mathrm{e}}^{\mathrm{t}}}
\end{aligned}
$$

Where $q_{e}$ undergoes the resin's adsorption capacity at $\mathrm{mmol} / \mathrm{g}, q_{t}$ represents the adsorbed value of metal ion at the time $(t), k_{1}$ and $k_{2}$ are the rate constants of the pseudo-first-order model at $1 / \mathrm{min}$ and the pseudo-second-order model at $\mathrm{g} \times(\mathrm{mmol} / \mathrm{min})[21]$.

\section{Dynamic Adsorption and Elution}

In this research work, the dynamic adsorption and elution of $\mathrm{Mg}^{2+}$ and $\mathrm{Ca}^{2+}$ ions on the SPVC (100 g) were carried out in a glass column (length: $50 \mathrm{~cm}$, width: $2 \mathrm{~cm}$ ). The procedure factors of dynamic adsorption and elution of selected ions are revealed in Table 2.

Table 2. Dynamic adsorption and elution procedure factors.

\begin{tabular}{ccccc}
\hline $\begin{array}{c}\text { Adsorption } \\
\text { numbers }\end{array}$ & $\begin{array}{c}\text { Feed } \\
\text { solutions }\end{array}$ & $\begin{array}{c}\text { Elution } \\
\text { flow } \\
\text { rate } \\
\text { (mL/min) }\end{array}$ & $\begin{array}{c}\text { Elution } \\
\text { numbers }\end{array}$ & $\begin{array}{c}\text { Elution } \\
\text { flow } \\
\text { rate } \\
\text { (mL/min) }\end{array}$ \\
\hline 1 & & 0.5 & 1 & 1 \\
2 & Pure water & 1 & 2 & 1 \\
3 & & 3 & 3 & 1 \\
4 & Industrial & 0.5 & 4 & 0.5 \\
5 & wastewater & 1 & 5 & 1 \\
6 & & 3 & 6 & 3 \\
\hline
\end{tabular}

The adsorption-elution procedures $\mathrm{Mg}^{2+}$ and $\mathrm{Ca}^{2+}$ ions on the SPVC resin were carried out according to follow steps [22]:

1. The SPVC resin was initial placed into the column, and then $250 \mathrm{~mL}$ industrial wastewater was passed via the column at 3 $\mathrm{mL} / \mathrm{min}$ flow speed. A peristaltic pump (Humboldt, Lab 2012) can control the flow rate. The deionized water used as a feed solution [23].
2. $0.25 \mathrm{~mol} / \mathrm{L} \mathrm{Mg}^{2+}$ and $\mathrm{Ca}^{2+}$ ions were mixed with the pure water, and the mixed solution was passed via the column upward at various flow rate according to Table 2 . After these procedures, the resulted samples in the effluents were placed out at regular intervals and tested by titrimetric analysis [24].

3. The industrial wastewater solution was passed via the column upward at various flow rates according to Table 2. After these procedures, the resulted samples in the effluents were placed out at regular intervals and tested by the atomic adsorption spectroscopes [25].

4. The following adsorption and elution acts of selected ions were run according to 1,2 and 3 processes at the procedure factors, which are presented in Table 2.

The breakthrough curves of $\mathrm{Mg}^{2+}$ and $\mathrm{Ca}^{2+}$ ions were measured according to the Thomas model, which anticipates the adsorption and elution processes $\mathrm{Mg}^{2+}$ and $\mathrm{Ca}^{2+}$ ions through the selected resin and the kinetics of the second-order was the reversible reaction. This model can be described in eq. (6) [26].

$\frac{\mathrm{C}}{\mathrm{C}_{\mathrm{o}}}=\frac{1}{1+\frac{\operatorname{expk}_{\mathrm{T}}}{\mathrm{Q}\left(\mathrm{q}_{\mathrm{m}} \mathrm{W}-\mathrm{C}_{\mathrm{o}} \mathrm{V}_{\text {out }}\right)}}$

Where $C$ represents the outlet metal concentration $(\mathrm{mol} / \mathrm{L})$ at various effluent volumes; $C_{o}$ shows the inlet metal concentrations $(\mathrm{mol} / \mathrm{L}) ; \quad q_{m}$ is the maximum sorption capacity of metal ion per unit mass of resin $(\mathrm{mmol} / \mathrm{g}) ; V_{\text {out }}$ is the effluent volume $(\mathrm{mL})$ and $W$ is the resin dosage in the fixed bed column $(\mathrm{g}) ; k_{T}$ is the Thomas rate constant $[\mathrm{L} /(\mathrm{mol} \cdot \mathrm{min})]$ and $Q$ is the volumetric flow rate $(\mathrm{mL} / \mathrm{min})$ [27]. 


\section{Results and Discussion Batch Adsorption Isotherms}

The adsorption isotherms (Fig. 1) in the pure water can identify the adsorption characterizes of $\mathrm{Mg}^{2+}$ and $\mathrm{Ca}^{2+}$ ions on the SPVC resin in the range between 15-300 $\mathrm{mmol} / \mathrm{L}$ concentrations. As observed, the adsorption capacity of the SPVC resin for $\mathrm{Mg}^{2+}$ and $\mathrm{Ca}^{2+}$ ions rose dramatically from 1.5 $\mathrm{mmol} / \mathrm{g}$ to $3.5 \mathrm{mmol} / \mathrm{g}$; afterwards, this trend remained stable around $3.75 \mathrm{mmol} / \mathrm{g}$. These results indicated that the maximum adsorption capacity of the selected resin was $3.78 \mathrm{mmol} / \mathrm{g}$ for $\mathrm{Ca}^{2+}$ ions and $3.74 \mathrm{mmol} / \mathrm{g}$ for $\mathrm{Mg}^{2+}$ ions. This is due to the ionic radius of $\mathrm{Ca}^{2+}$ ions are lower than that of $\mathrm{Mg}^{2+}$ ions, indicating that $\mathrm{Ca}^{2+}$ ions a higher hydration energy and a lower tendency to migrate into the resin than that of $\mathrm{Mg}^{2+}$ ions. These results confirmed that the studied resin has great adsorption capacity for $\mathrm{Mg}^{2+}$ and $\mathrm{Ca}^{2+}$ ions [28].

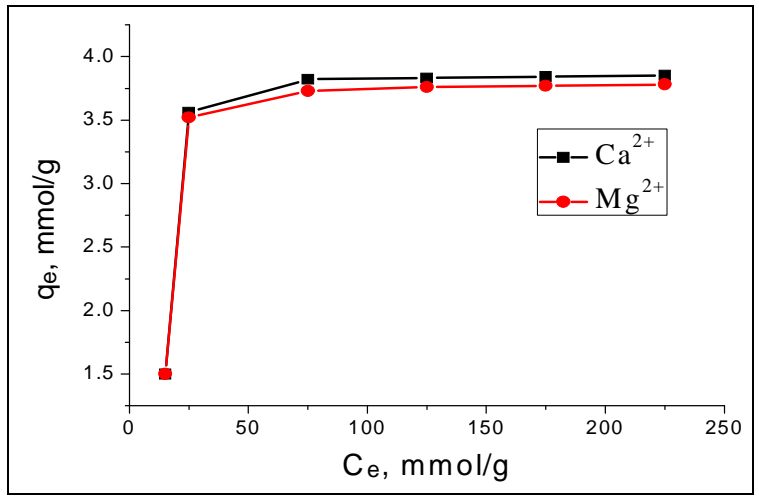

Figure 1. Adsorption isotherms of $\mathrm{Mg}^{2+}$ and $\mathrm{Ca}^{2+}$ ions in pure water

The adsorption processes of $\mathrm{Mg}^{2+}$ and $\mathrm{Ca}^{2+}$ ions in the resin was also studied using Langmuir and Freundlich isotherms, as presented in Fig. 2a and Fig. 2b. The observed results confirmed that Freundlich isotherms are a lower comfortable empirical isotherm for non-ideal adsorption [29]. The correlation coefficients of Langmuir and Freundlich adsorption isotherms for $\mathrm{Mg}^{2+}$ and $\mathrm{Ca}^{2+}$ ions in pure water were found and given in
Table 3. General, it is a clear fact from Table 3 that the correlation coefficient was 0.997 for the $\mathrm{Ca}^{2+}$ ions and 0.998 for $\mathrm{Mg}^{2+}$ ions according to Langmuir isotherms. In contrast, the correlation coefficient was 0.621 for $\mathrm{Ca}^{2+}$ ions and $0.674 \mathrm{Mg}^{2+}$ ions related to Freundlich isotherms. These findings confirmed that the Langmuir isotherms are better fitting than Freundlich isotherms. Another interesting point is that the selected resin's maximal adsorption capacities were $3.78 \mathrm{mmol} / \mathrm{g}$ for $\mathrm{Ca}^{2+}$ ions and $3.74 \mathrm{mmol} / \mathrm{g}$ for $\mathrm{Mg}^{2+}$ ions.
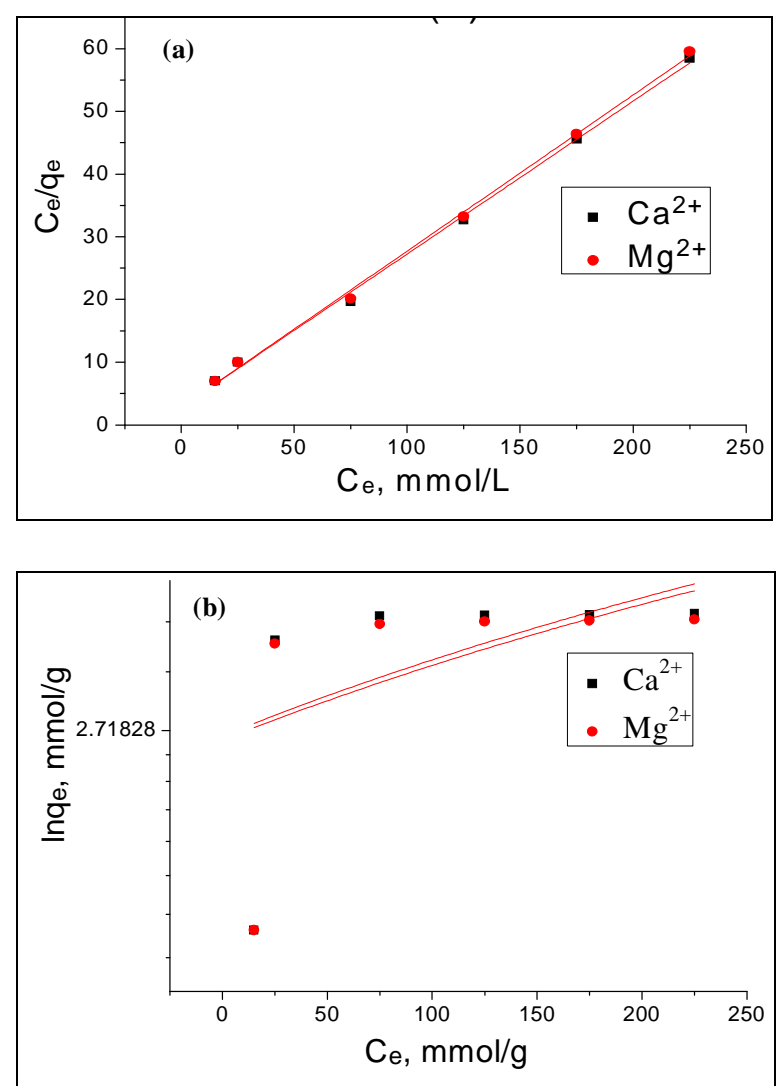

Figure 2. (a) Langmuir and (b) Freundlich adsorption isotherms for $\mathrm{Mg}^{2+}$ and $\mathrm{Ca}^{2+}$ ions in the pure water

Table 3. Correlation coefficients of Freundlich and Langmuir adsorption isotherms for $\mathrm{Mg}^{2+}$ and $\mathrm{Ca}^{2+}$ ions in pure water.

\begin{tabular}{|c|c|c|c|c|c|c|}
\hline \multirow{2}{*}{$\begin{array}{c}\text { Metal } \\
\text { ions }\end{array}$} & \multicolumn{3}{|c|}{ Langmuir isotherms } & \multicolumn{3}{|c|}{ Freundlich isotherms } \\
\hline & $\begin{array}{c}b \\
g / m m o l\end{array}$ & $\begin{array}{c}q_{m} \\
\mathrm{mmol} / \mathrm{g}\end{array}$ & $R^{2}$ & $\begin{array}{c}k_{f} \\
\mathrm{mmol} / \mathrm{L}\end{array}$ & $n$ & $R^{2}$ \\
\hline $\mathrm{Ca}^{2+}$ & 0.14 & 3.78 & 0.997 & 0.78 & 5.94 & 0.621 \\
\hline $\mathrm{Mg}^{2+}$ & 0.18 & 3.74 & 0.998 & 0.81 & 6.52 & 0.674 \\
\hline
\end{tabular}




\section{Batch Adsorption Kinetics}

The adsorption kinetics is the next significant indicator to characterize the adsorption efficiency of metal ions on the sorbent resin [30]. The adsorption kinetics of $\mathrm{Mg}^{2+}$ and $\mathrm{Ca}^{2+}$ ions on the selected strong acid resin in pure water and selected industrial wastewater solutions were investigated to explore the adsorption process of metal ions on the resin and the adsorption capacity of SPVC resin for $\mathrm{Mg}^{2+}$ and $\mathrm{Ca}^{2+}$ ions; the observed results are indicated in Figure 3. In these figures, the pseudo-second-order model and the pseudo-first-order model were used to fit the observed results. The resulted correlation coefficients are given in Table 4 and Table 5.

Table 4. The pseudo-first-order model and the pseudo-second-order model parameters for $\mathrm{Ca}^{2+}$ ions.

\begin{tabular}{ccccccc}
\hline \multirow{2}{*}{ Solutions } & \multicolumn{3}{c}{$\begin{array}{c}\text { Pseudo-first-order } \\
\text { model }\end{array}$} & \multicolumn{3}{c}{$\begin{array}{c}\text { Pseudo-second-order } \\
\text { model }\end{array}$} \\
\cline { 2 - 7 } & $\mathbf{R}^{\mathbf{2}}$ & $\boldsymbol{q}_{\boldsymbol{e}}$ & $\boldsymbol{k}_{\boldsymbol{1}}$ & $\mathbf{R}^{\mathbf{2}}$ & $\boldsymbol{q}_{\boldsymbol{e}}$ & $\boldsymbol{k}_{\mathbf{2}}$ \\
\hline Pure water & 0.997 & 3.76 & 2.2 & 0.985 & 3.79 & 2.8 \\
Industrial & 0.984 & 2.52 & 0.7 & 0.974 & 2.45 & 7.7 \\
wastewater & & & & & & \\
\hline
\end{tabular}

Table 5. The pseudo-first-order model and the pseudo-second-order model parameters for $\mathrm{Mg}^{2+}$ ions.

\begin{tabular}{ccccccc}
\hline \multirow{2}{*}{ Solutions } & \multicolumn{2}{c}{$\begin{array}{c}\text { Pseudo-first-order } \\
\text { model }\end{array}$} & \multicolumn{3}{c}{$\begin{array}{c}\text { Pseudo-second-order } \\
\text { model }\end{array}$} \\
\cline { 2 - 7 } & $\mathbf{R}^{\mathbf{2}}$ & $\boldsymbol{q}_{\boldsymbol{e}}$ & $\boldsymbol{k}_{\boldsymbol{1}}$ & $\mathbf{R}^{\mathbf{2}}$ & $\boldsymbol{q}_{\boldsymbol{e}}$ & $\boldsymbol{k}_{\boldsymbol{2}}$ \\
\hline Pure water & 0.994 & 3.69 & 1.8 & 0.981 & 3.73 & 2.4 \\
$\begin{array}{c}\text { Industrial } \\
\text { wastewater }\end{array}$ & 0.974 & 2.35 & 0.5 & 0.976 & 2.44 & 6.5 \\
\hline
\end{tabular}

Figure $3 \mathrm{a}$ and Figure $3 \mathrm{~b}$ illustrate that the adsorption rate of $\mathrm{Mg}^{2+}$ and $\mathrm{Ca}^{2+}$ ions in the pure water is very fast, and the adsorption processes reached equilibrium after $10 \mathrm{~min}$ contact time. Nevertheless, the adsorption rate of $\mathrm{Mg}^{2+}$ and $\mathrm{Ca}^{2+}$ ions in the industrial wastewater was slowly, and their adsorption processes on resin reached equilibrium after $60 \mathrm{~min}$ contact time. The adsorption rate stabilized around $3.76 \quad \mathrm{mmol} / \mathrm{g}$ (Pseudo-first-order model) and $3.79 \mathrm{mmol} / \mathrm{g}$ (pseudo-second-order model) for $\mathrm{Ca}^{2+}$ ions, and $3.69 \mathrm{mmol} / \mathrm{g}$ (pseudo-first-order model) and $3.73 \mathrm{mmol} / \mathrm{g}$ (pseudo-second-order model) for $\mathrm{Mg}^{2+}$ ions in pure water, respectively. However, these values were slowly reduced in the industrial wastewater because the industrial wastewater influences the adsorption processes. As can be observed from Table 4 and Table 5, the correlation coefficient $k_{2}$ increased while $k_{1}$ decreased. For instance, the amounts of $k_{2}$ for $\mathrm{Ca}^{2+}$ ion 2.8 and $7.7 \mathrm{~g}(\mathrm{mmol} / \mathrm{min})$ in pure water and industrial wastewater, respectively, while the amounts of $k_{l}$ for $\mathrm{Ca}^{2+}$ ion were 1.8 and 0.5 $\min ^{-1}$ in the pure water and industrial wastewater, respectively. The amounts of $k_{l}$ and $k_{2}$ for $\mathrm{Mg}^{2+}$ ions were similar to $\mathrm{Ca}^{2+}$. Moreover, it can be illustrated that the adsorption capacity of the selected resin was lower in the industrial wastewater than that in pure water. This is due to the dissociation constant of metal ions higher in pure water than in industrial water. The more dissociated metal ions are easily adsorbed on the resin. These results confirmed that the adsorption capacity of the selected resin was high in both pure water and industrial wastewater.
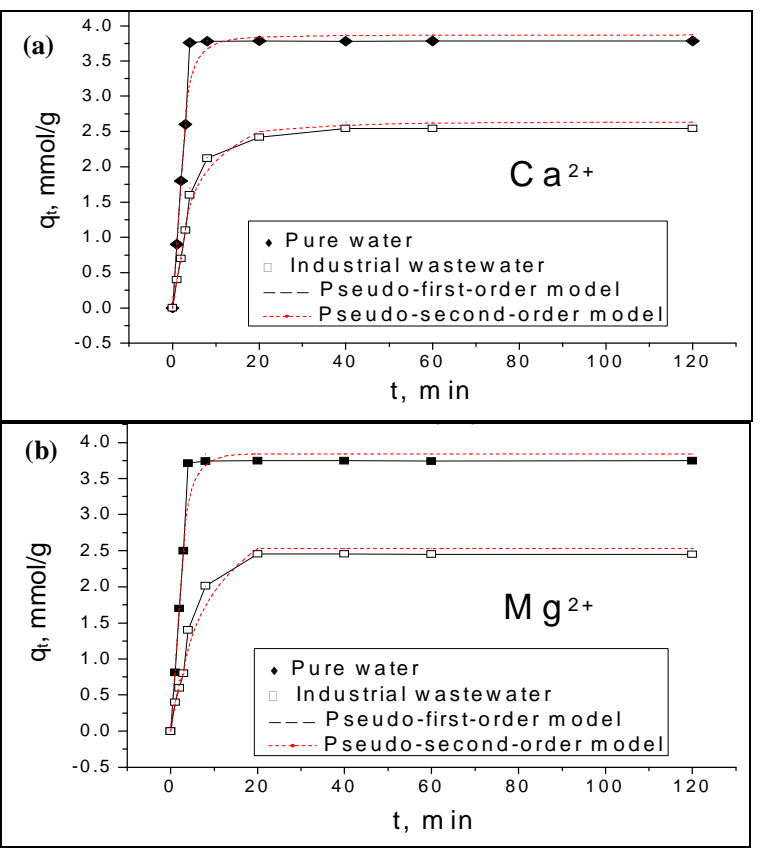

Figure 3. Adsorption kinetics of (a) $\mathrm{Ca}^{2+}$ and (b) $\mathrm{Mg}^{2+}$ ions in pure water and industrial wastewater solution 


\section{Dynamic Adsorption}

In practical observation, dynamic adsorption is the most common way to test the adsorption capacity of the studied resin. In this research work, the dynamic adsorption capacity of the SPVC for $\mathrm{Mg}^{2+}$ and $\mathrm{Ca}^{2+}$ ions in pure water and industrial wastewater was investigated. The observed data and Thomas fitting plots are indicated in Fig. $4 \mathrm{a}$ and Fig. 4b, the correlation coefficients are presented in Table 6. As observed, the dynamic column adsorption can separate simultaneously $\mathrm{Mg}^{2+}$ and $\mathrm{Ca}^{2+}$ ions from industrial wastewater and pure water. Fig. 5a and Fig. $5 \mathrm{~b}$ show that the break volumes $\left(\mathrm{C} / \mathrm{C}_{0}\right.$ $>0$ ) for the industrial wastewater and pure water are $225 \mathrm{~mL}$ and $150 \mathrm{~mL}$, respectively. It is a point that a difference in the adsorption capacity of SPVC resin for $\mathrm{Mg}^{2+}$ and $\mathrm{Ca}^{2+}$ ions in pure water and industrial wastewater is lower in the dynamic column adsorption. Overall, what stands out from the observed results in Table 6 is that the dynamic adsorption capacity of the selected resin is $2.15 \mathrm{mmol} / \mathrm{g}$ in pure water and $1.89 \mathrm{mmol} / \mathrm{g}$ in industrial wastewater. The difference in the batch adsorption and dynamic column adsorption were $(3.78-2.15) / 3.78=43.12 \%$ (Table 6) in pure water, and $(2.5-1.89) / 2.5=24.4 \%$, confirmed that SPVC resin is high dynamic adsorption capacity for $\mathrm{Mg}^{2+}$ and $\mathrm{Ca}^{2+}$ ions in industrial wastewater. When the flow rate was increased from 0.5 $\mathrm{mL} / \mathrm{min}$ to $3 \mathrm{~mL} / \mathrm{min}$, the dynamic adsorption capacity decreased slowly (Table 6) and save the adsorption capacity. This phenomenon suggests that this resin is an effective metal separator in a dynamic condition.

On the other hand, it would be stated that the dynamic adsorption nature of studied resin for $\mathrm{Mg}^{2+}$ and $\mathrm{Ca}^{2+}$ ions in the pure water nearly stable at the different flow rates, which the saturation coefficient $\left(\mathrm{C} / \mathrm{C}_{0}=1\right)$ sharply increased at $250 \mathrm{~mL}$ fed solution and break indicator cited at $225 \mathrm{~mL}$ feed solution. Nevertheless, the dynamic adsorption column capacity in industrial wastewater differs from that in pure water. As observed, the saturation amount appeared at $200 \mathrm{~mL}$ and the broken volume cited at $150 \mathrm{~mL}$ in $0.5 \mathrm{~mL} / \mathrm{min}$ flow rate. When the flow rate reached $3 \mathrm{~mL} / \mathrm{min}$, the saturation amount appeared at $225 \mathrm{~mL}$, and the broken volume located at $75 \mathrm{~mL}$. These trends confirmed that the rise in flow rate influence the diffusion of metal ions in the industrial wastewater solution. It can be summarized that the flow rate influences the dynamic adsorption capacity of resin in the solutions, indicating that this resin is an excellent separating agent for $\mathrm{Mg}^{2+}$ and $\mathrm{Ca}^{2+}$ ions in the industrial wastewater at the dynamic condition.
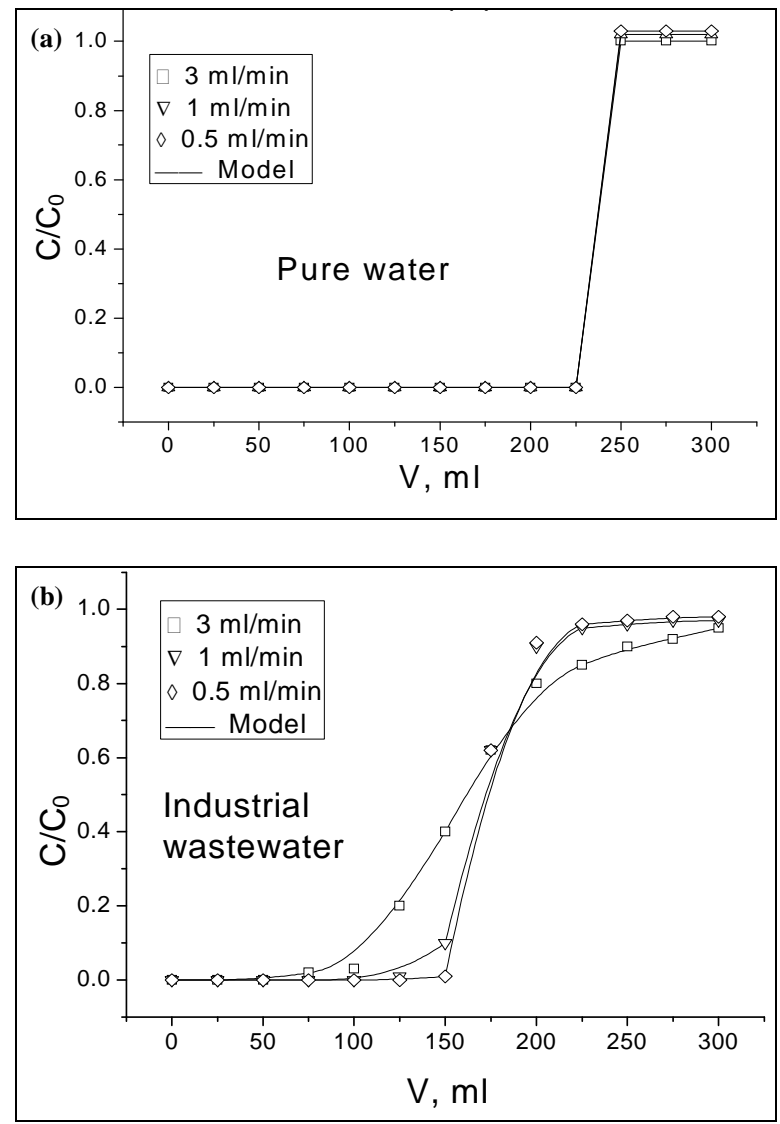

Figure 4. Breakthrough nature of the metal ions in (a) pure water and (b) industrial wastewater 
Table 6. Characteristics of the Thomas model for the dynamic separation of $\mathrm{Mg}^{2+}$ and $\mathrm{Ca}^{2+}$ ions.

\begin{tabular}{lcccccc}
\hline \multirow{2}{*}{$\begin{array}{l}\text { Flow rate } \\
(\mathbf{m L} / \mathbf{m i n})\end{array}$} & \multicolumn{3}{c}{ Pure water } & \multicolumn{3}{c}{ Industrial wastewater } \\
\cline { 2 - 7 } & $\boldsymbol{k}_{\boldsymbol{T}}$ & $\boldsymbol{q}_{\boldsymbol{o}}$ & $\mathbf{R}^{\mathbf{2}}$ & $\boldsymbol{k}_{\boldsymbol{T}}$ & $\boldsymbol{q}_{\boldsymbol{o}}$ & $\mathbf{R}^{\mathbf{2}}$ \\
\hline 0.5 & 0.92 & 2.15 & 0.994 & 0.86 & 1.89 & 0.991 \\
1 & 0.86 & 2.11 & 0.991 & 0.81 & 1.85 & 0.992 \\
3 & 0.78 & 2.01 & 0.993 & 0.76 & 1.81 & 0.994 \\
\hline
\end{tabular}

\section{Dynamic Elution}

In the next part of this research work, the dynamic elution of $\mathrm{Mg}^{2+}$ and $\mathrm{Ca}^{2+}$ ions from SPVC resin was investigated, and the observed results are given in Fig. 5 and Table 7. $5 \mathrm{~mol} / \mathrm{L} \mathrm{H}_{2} \mathrm{SO}_{4}$ was selected as a regenerated solution for the resin. It should be underlined that the elution of flow rate slowly influenced the dynamic elution nature of metal ions. The elution procedure was nearly similar at $0.5,1$ and $3 \mathrm{~mL} / \mathrm{min}$. The peak amount of elution plots and the elution values of metal ions accounted for $1.31 \mathrm{~mol} / \mathrm{L}$ and 85.11 $\mathrm{mmol}$ at $0.5 \mathrm{~mL} / \mathrm{min}, 0.3 \mathrm{~mol} / \mathrm{L}$ and 83.15 $\mathrm{mmol}$ at $1 \mathrm{~mL} / \mathrm{min}$, and $1.1 \mathrm{~mol} / \mathrm{L}$ and 79.11 mmol, respectively.

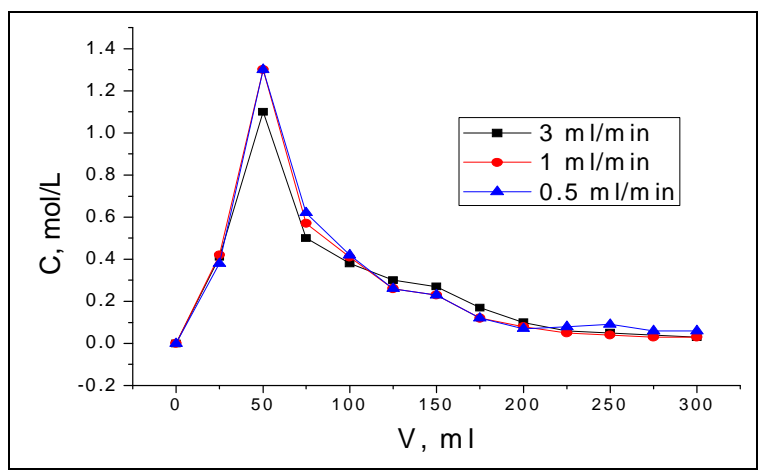

Figure 5. Elution plots of the metal ions

Table 7. Elution and adsorption values of metal ions measured by the elution and breakthrough plots for the 6 elution and adsorption procedures.

\begin{tabular}{cccc}
\hline $\begin{array}{c}\text { Elution flow } \\
\text { rate } \\
(\mathbf{m L} / \mathbf{m i n})\end{array}$ & $\begin{array}{c}\text { Elution } \\
\text { quantities } \\
(\mathbf{m m o l})\end{array}$ & $\begin{array}{c}\text { Adsorption } \\
\text { flow rate } \\
(\mathbf{m L / m i n})\end{array}$ & $\begin{array}{c}\text { Adsorption } \\
\text { quantities } \\
\text { (mmol) }\end{array}$ \\
\hline 1 & 118.61 & 0.5 & 125.14 \\
1 & 121.43 & 1 & 126.51 \\
1 & 116.47 & 3 & 124.87 \\
0.5 & 85.11 & 0.5 & 88.75 \\
1 & 83.15 & 1 & 89.31 \\
3 & 79.31 & 3 & 88.12 \\
\hline
\end{tabular}

The next notable feature from observed data is that $5 \mathrm{~mol} / \mathrm{L} \mathrm{H}_{2} \mathrm{SO}_{4}$ is the excellent regenerate solution for SPVC resin. The adsorption capacity of regenerated SPVC resin for selected metal ions was similar to the new SPVC resin. Table 7 indicates that the adsorption values of metal ions were stabilized around 121.43-125.14 and $83.15-88.75 \mathrm{mmol}$ in the pure and industrial wastewater solutions, respectively. It is also described that the adsorption values of metal ions were greater than the elution values of metal ions in 6 procedures because the deionized water influences the washing resin.

\section{Effect of Temperature}

The influence of temperature on the adsorption of $\mathrm{Mg}^{2+}$ and $\mathrm{Ca}^{2+}$ ions in SPVC resin in the industrial wastewater in the range of $293-333 \mathrm{~K}$ at different time intervals (2-300 min) was investigated; the observed results are given in Fig. 6.
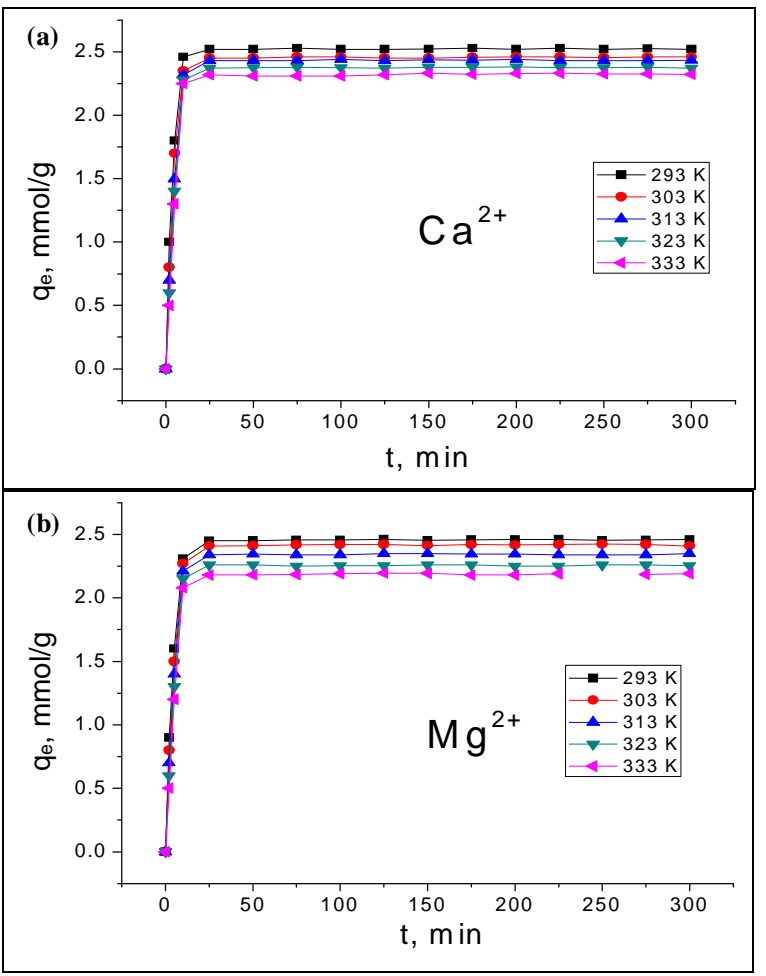

Figure 6. Effect of temperature on the adsorption $\mathrm{Ca}^{2+}$ and $\mathrm{Mg}^{2+}$ ions to SPVC resin in the industrial wastewater 
General, it is evident that the amounts of $\mathrm{Mg}^{2+}$ and $\mathrm{Ca}^{2+}$ ions adsorbed at equilibrium $\left(\mathrm{q}_{\mathrm{e}}\right)$ were cited between $1.51-1.78 \mathrm{mmol} / \mathrm{g}$ and $1.42-1.68 \mathrm{mmol} / \mathrm{g}$, respectively. The sorption efficiency of the selected resin nearly stable in the rise of temperature. It is also confirmed that the sorption processes on the selected resin are endothermic. Therefore, the rise of temperature slowly influenced the adsorption $\mathrm{Mg}^{2+}$ and $\mathrm{Ca}^{2+}$ ions in SPVC resin.

\section{Adsorption Thermodynamics}

The change in the standard Gibbs free energy $\left(\Delta \mathrm{G}^{\circ}\right)$ and equilibrium constant $\left(\mathrm{K}_{\mathrm{c}}\right)$ of the adsorption of $\mathrm{Mg}^{2+}$ and $\mathrm{Ca}^{2+}$ ions on SPVC resin in the industrial wastewater in the range of $293-333 \mathrm{~K}$ were measured according to eq. (7) and eq. (8). Next, the measured $\mathrm{K}_{\mathrm{c}}$ values are utilized to calculate the plot of $\ln \mathrm{K}_{\mathrm{c}}$ versus $1 / \mathrm{T}$ for $\mathrm{Mg}^{2+}$ and $\mathrm{Ca}^{2+}$ ions (Fig. 7). The change in the standard enthalpy $\left(\Delta \mathrm{H}^{\circ}\right)$ and in the standard entropy $\left(\Delta \mathrm{S}^{\circ}\right)$ of the adsorption of $\mathrm{Mg}^{2+}$ and $\mathrm{Ca}^{2+}$ ions on SPVC resin in the industrial wastewater were measured from an intercept and slope related to eq. (9) [30], respectively.

$$
\begin{aligned}
& \Delta \mathrm{G}^{\mathrm{o}}=-\mathrm{RT} \ln \mathrm{K}_{\mathrm{c}} \\
& \mathrm{K}_{\mathrm{c}}=\frac{\mathrm{C}_{\mathrm{Re}}}{\mathrm{C}_{\mathrm{Se}}} \\
& \ln \mathrm{K}_{\mathrm{c}}=\frac{-\Delta \mathrm{H}^{\mathrm{o}}}{\mathrm{RT}}+\frac{\Delta \mathrm{S}^{\mathrm{o}}}{\mathrm{R}}
\end{aligned}
$$

where $\mathrm{C}_{\mathrm{Se}}$ indicates the equilibrium quantity of metal ions in the solution; $C_{R e}$ shows the equilibrium concentration of the sorbed metal ions; $\mathrm{R}$ is $8.314 \mathrm{~J} / \mathrm{mol} \times \mathrm{K}$; $\mathrm{T}$ is the temperature [31].

Table 8 and Table 9 represent the adsorption thermodynamic parameters for $\mathrm{Mg}^{2+}$ and $\mathrm{Ca}^{2+}$ ions in the industrial wastewater at various temperatures. General, the negative values of standard Gibbs energy indicate that the adsorption of $\mathrm{Mg}^{2+}$ and $\mathrm{Ca}^{2+}$ ions on the selected resin is a spontaneous process [32, 33]. The amount of $\Delta G^{\circ}$ decreased slowly with the rise of temperature, indicating that the adsorption of $\mathrm{Ca}^{2+}$ and $\mathrm{Mg}^{2+}$ ions rose in an increase of temperature. It is also reported that $\mathrm{K}_{\mathrm{c}}$ increased slowly with the rise of temperature and $\Delta \mathrm{H}^{\circ}$ is positive, representing that the adsorption of $\mathrm{Mg}^{2+}$ and $\mathrm{Ca}^{2+}$ ions on the selected resin is endothermic $[34,35]$. The change in the standard entropy shows the affinity of the resin to the $\mathrm{Mg}^{2+}$ and $\mathrm{Ca}^{2+}$ ions, and its negative amounts responsible for a decrease in randomness in the sorption of $\mathrm{Mg}^{2+}$ and $\mathrm{Ca}^{2+}$ ions. The negative value of $\Delta \mathrm{S}^{\circ}$ confirmed that the sorption of $\mathrm{Mg}^{2+}$ and $\mathrm{Ca}^{2+}$ ions are more stable.
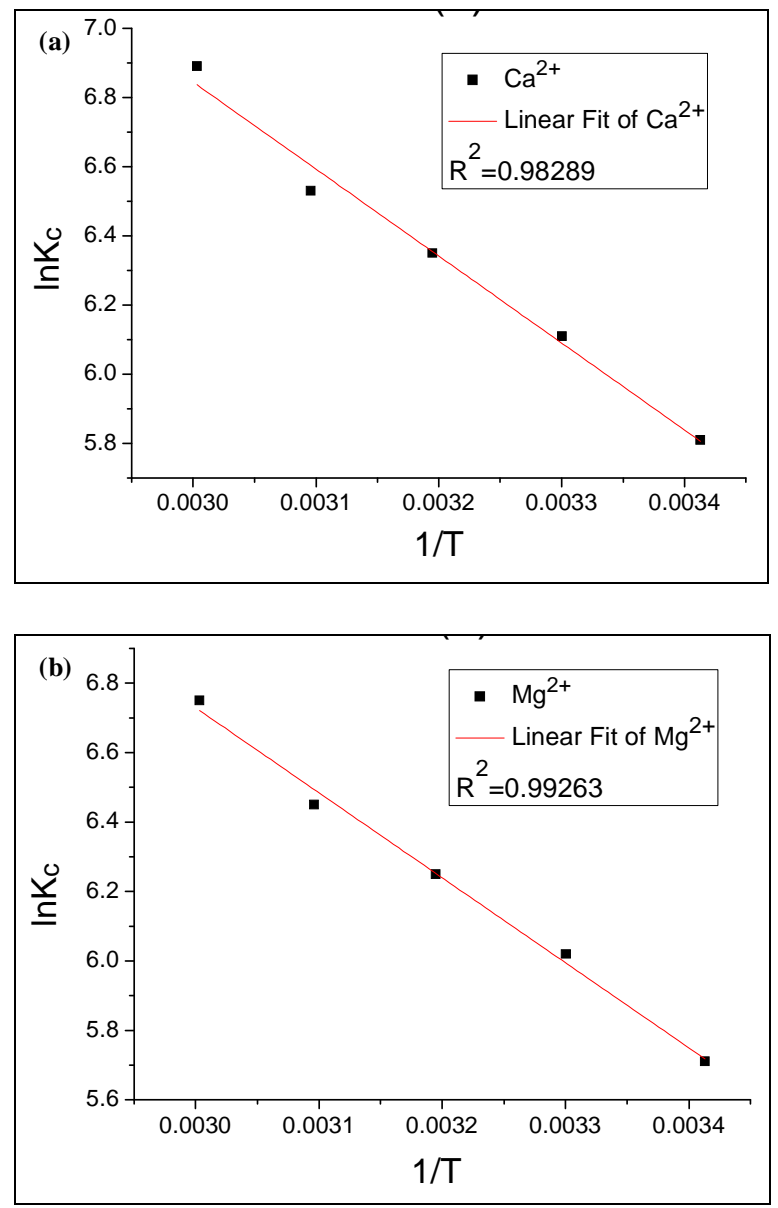

Figure 7. The plot of $\ln \mathrm{K}_{\mathrm{c}}$ versus $1 / \mathrm{T}$ for $\mathrm{Ca}^{2+}$ and $\mathrm{Mg}^{2+}$ ions 
Table 8. Estimated thermodynamic parameters for $\mathrm{Ca}^{2+}$ ions.

\begin{tabular}{lcccc}
\hline $\mathbf{T}(\mathbf{K})$ & $\mathbf{K}_{\mathbf{c}}$ & $\begin{array}{c}\Delta \mathbf{G}^{\circ} \\
(\mathbf{k J} / \mathbf{m o l})\end{array}$ & $\begin{array}{c}\Delta \mathbf{H}^{\circ} \\
(\mathbf{k J} / \mathbf{m o l})\end{array}$ & $\begin{array}{c}\Delta \mathbf{S}^{\circ} \\
\left(\mathbf{J} / \mathbf{M o l} \mathbf{l}^{*}\right)\end{array}$ \\
\hline 293 & 5.81 & -4284 & & \\
303 & 6.11 & -4557 & & \\
313 & 6.35 & -4807 & 14.38 & -2.513 \\
323 & 6.53 & -5036 & & \\
333 & 6.89 & -5340 & & \\
\hline
\end{tabular}

Table 9. Estimated thermodynamic parameters for $\mathrm{Mg}^{2+}$ ions.

\begin{tabular}{ccccc}
\hline $\mathbf{T}(\mathbf{K})$ & $\mathbf{K}_{\mathbf{c}}$ & $\begin{array}{c}\Delta \mathbf{G}^{\circ} \\
(\mathbf{k J} / \mathbf{m o l})\end{array}$ & $\begin{array}{c}\Delta \mathbf{H}^{\circ} \\
(\mathbf{k J} / \mathbf{m o l})\end{array}$ & $\begin{array}{c}\Delta \mathbf{S}^{\circ} \\
\left(\mathbf{J} / \mathbf{M o l} \mathbf{l}^{*}\right)\end{array}$ \\
\hline 293 & 5.71 & -4242 & & \\
303 & 6.02 & -4519 & & \\
313 & 6.25 & -4766 & 14.07 & -2.448 \\
323 & 6.45 & -5003 & & \\
333 & 6.75 & -5284 & & \\
\hline
\end{tabular}

\section{Conclusion}

In this research work, the adsorption equilibrium, kinetics, thermodynamics, and dynamic separation of magnesium and calcium ions from industrial wastewater by strong acid cation resin were investigated and summarized. SPVC strong acid cation resin effectively separated magnesium and calcium ions from the industrial wastewater at 293-333 K temperature ranges. The dynamic separation observation confirmed that the selected resin effectively separated magnesium and calcium ions from pure water and industrial wastewater in dynamic condition and easily regenerated with $5 \mathrm{~mol} / \mathrm{L}$ $\mathrm{H}_{2} \mathrm{SO}_{4}$. The obtained thermodynamic parameters revealed that the studied adsorption is endothermic. The Langmuir isotherm results indicated that the adsorption capacity of the studied resin was $3.78 \mathrm{mmol} / \mathrm{g}$ and $3.74 \mathrm{mmol} / \mathrm{g}$ for magnesium and calcium ions, respectively. The pseudo-first-order model was better fitted for the adsorption kinetics of magnesium and calcium ions on the resin. The adsorption equilibriums are reached within $10 \mathrm{~min}$ contact time. The sorption capacity of the selected resin was not changed with a rise of the flow rate.

\section{Conflict of Interest}

The authors declare that there is no conflict of interest.

\section{References}

1. R. Lü, Q. Xi, T. Li, R. Li, X. Zhang, J. Liu, C. Fan, J. Feng, L. Zhang and Z. Wang, Chin. J. Chem. Eng., 27 (2019) 12.

https://doi.org/10.1016/j.cjche.2018.12.025

2. Z. Yu, T. Qi, J. Qu, L. Wang and J. Chu, J. Hazard. Mater., 167 (2008) 406. https://doi.org/10.1016/j.jhazmat.2008.1 $\underline{2.140}$

3. C. Özmetin, Ö. Aydın, M. M. Kocakerim, M. Korkmaz and E. Özmetin, Chem. Eng. J., 148 (2009) 420.

https://doi.org/10.1016/j.cej.2008.09.021

4. D. Nuriddinova and F. Yusupov, Int. J. Eng. Technol., 9 (2020) 3.

https://doi.org/10.35940/ijitee.C8193.01 $\underline{9320}$

5. A. V. Singh, N. K. Sharma and A. S. Rathore, Environ. Technol., 33 (2012) 4. https://doi.org/10.1080/09593330.2011. $\underline{579184}$

6. N. A. Mirzaeva, A. P. Marinova, Kh. F. Mammadov, N. T. Temerbulatova, J. Kozempel and D. V. Filosofov, Russ. J. Phys. Chem., 94 (2020) 6. https://doi.org/10.1134/S003602442006 0175

7. T. N Nesterova, D. A Chernyshov, V. A Shakun, Catal. Ind., 8 (2016)16. https://doi.org/10.1134/S207005041601 $\underline{0086}$

8. P. N. Nesterenko, P. A. Kebets and Y. V. Volgin, J. Anal. Chem., 56 (2001) 715.

https://doi.org/10.1023/A:1016777409132

9. X. Leng, Y. Zhong, D. Xu, X. Wang and L. Yang, Chin. J. Chem. Eng., 27 (2019) 5.

https://doi.org/10.1016/j.cjche.2018.09.012 
10. A. Elgoud, E. M. Ismail, Z. H. Ahmad, Y. A. El-Nadi, S. M. Abdelwahab and H. F. Aly, Russ. J. Appl. Chem., 92 (2019) 1837.

https://doi.org/10.1134/S107042721912 $\underline{0290}$

11. K. Z Elwakeel, A. S Al-Bogami and E. Guibal, Chem. Eng. J., 403 (2021) 126265.

https://doi.org/10.1016/j.cej.2020.126265

12. I. Vergili, Z. B Gönder, Y. Kaya, G. Gürdağ and S. Çavuş, Process. Saf. Environ. Prot., 107 (2017) 498.

http://dx.doi.org/10.1016/j.psep.2017.03 .018

13. C. Muntean, W. Brandl, A. Iovi and P. Negrea, Thermochim. Acta, 439 (2005) 21. https://doi.org/10.1016/j.tca.2005.09.008

14. M. Alemrajabi, A. C. Rasmuson, K. Korkmaz and K. Forsberg, Hydrometallurgy, 169 (2017) 253.

https://doi.org/10.1016/j.hydromet.2017. $\underline{01.008}$

15. Y. K. Leong, M. Sganzerla, C. C. Berndt and G. R. Campbell, Ind. Eng. Chem. Res., 47 (2008) 5. https://doi.org/10.1021/ie071099m

16. H. Wang, R. Li, C. M. Fan, J. Q. Feng, S. L. Jiang and Z. M. Han, J. Fluorine Chem., 180 (2015) 122.

https://doi.org/10.1016/j.jfluchem.2015. $\underline{09.009}$

17. I. Hussain, Procedia Eng., 46 (2012) 172.

https://doi.org/10.1016/j.proeng.2012.09 .462

18. G. J. Millar, S. J. Couperthwaite, M. D. Bruyn and C. W. Leung, Chem. Eng. J., 280 (2015) 525. https://doi.org/10.1016/j.cej.2015.06.008

19. A. Malovanyy, H. Sakalova, Y. Yatchyshyn, E. Plaza and M. Malovanyy, Desalination, 329 (2013) 93.

https://doi.org/10.1016/j.desal.2013.09.009
20. N. Kabay, M. Demircioğlu, H. Ekinci, M. Yüksel, M. Sağlam, M. Akçay and M. Streat, Ind. Eng. Chem. Res., 37 (1998) 6.

https://doi.org/10.1021/ie9704881

21. E. Berdimurodov, A. Kholikov, K. Akbarov, G. Xu, A. M. Abdullah and M. Hosseini, Arab. J. Chem., 13 (2020) 10. https://doi.org/10.1016/j.arabjc.2020.08.025

22. W. T. Yi, C. Y. Yan and P. H. Ma, Desalination, 249 (2009) 2. https://doi.org/10.1016/j.desal.2009.01.034

23. J. P. Michael, S. Karin and D. O. Mark, Hydrometallurgy, 169 (2017) 275. https://doi.org/10.1016/j.hydromet.2017. $\underline{02.006}$

24. Z. H. Yu, T. Qi, J. K. Qu and Y. C. Guo, Hydrometallurgy, 158 (2015) 165.

https://doi.org/10.1016/j.hydromet.2015. $\underline{10.015}$

25. E. Berdimurodov, A. Kholikov, K. Akbarov and L. Guo, J. Mol. Liq., 335 (2021) 116168. https://doi.org/10.1016/j.molliq.2021.11 $\underline{6168}$

26. J. P. Chen, M. L. Chua and B. P. Zhang, Waste Manage., 22 (2002) 7.

https://doi.org/10.1016/S0956053X(02)00051-X

27. E. Berdimurodov, A. Kholikov, K. Akbarov and L. Guo, J. Mol. Liq., 327 (2021) 114813. https://doi.org/10.1016/j.molliq.2020.11 4813

28. T. N. Nesterova, D. A. Chernyshov, V. A. Shakun, N. Yu. Krymkin, A. V. Tarasov, I. O. Voronin and N. V. Bilenchenko, Catal. Ind., 8 (2016) 1. https://doi.org/10.1134/S207005041601 $\underline{0086}$

29. E. Berdimurodov, A. Kholikov, K. Akbarov, L. Guo, A. M. Abdullah and M. Elik, J. Mol. Liq., 328 (2021) 115475. https://doi.org/10.1016/j.molliq.2021.11 $\underline{5475}$ 
30. U. K. Sahu, S. Sahu, S. S. Mahapatra and R. K. Patel, Environ. Sci. Pollut. Res., 26 (2019) 1.

https://doi.org/10.1007/s11356-0183643-1

31. D. K. Verma, M. Kazi, M. S. Alqahtani, R. Syed, E. Berdimurodov, S. Kaya, R. Salim, A. Asatkar and R. Haldhar, J. Mol. Struct., 1241 (2021) 130648.

https://doi.org/10.1016/j.molstruc.2021. 130648

32. U. K. Sahu, S. Sahu, S. S. Mahapatra and R. K Patel, J. Mol. Liq., 243 (2017) 395.

https://doi.org/10.1016/j.molliq.2017.08.055
33. E. Berdimurodov, A. Kholikov, K. Akbarov, I.B. Obot and L. Guo, J. Mol. Struct., 1234 (2021) 130165. https://doi.org/10.1016/j.molstruc.2021. 130165

34. S. Sahu, P. Kar, N. Bishoyi, L. Mallik and R. K Patel, J. Chem. Eng., 64 (2019) 10.

https://doi.org/10.1021/acs.jced.9b00444

35. A. R Shahmoradi, M. Ranjbarghanei, A. A. Javidparvar, L. Guo, E. Berdimurodov and B. Ramezanzadeh, $J$. Mol. Liq., 338 (2021). https://doi.org/10.1016/j.molliq.2021.11 $\underline{6550}$ 